64

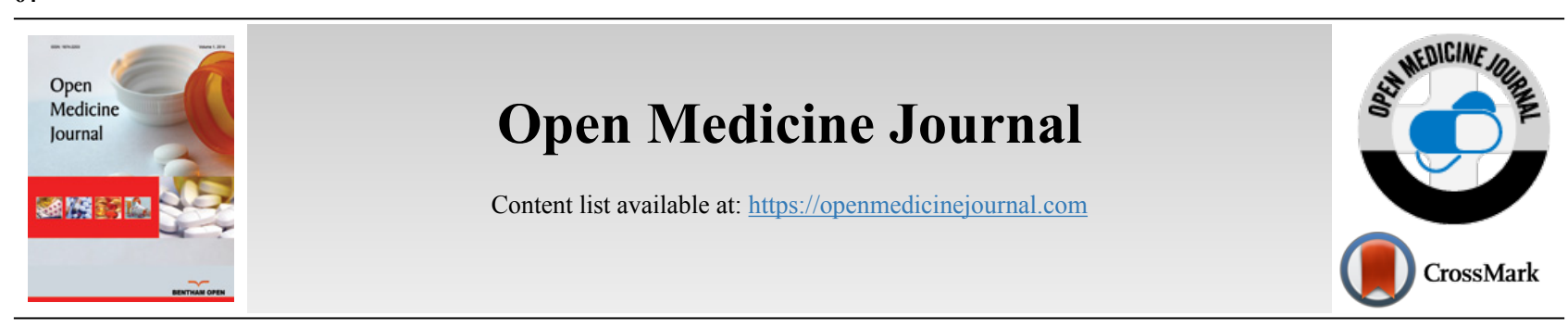

REVIEW ARTICLE

\title{
A Detailed Insight of the Anti-inflammatory Effects of Curcumin with the Assessment of Parameters, Sources of ROS and Associated Mechanisms
}

\author{
Pranay Wal ${ }^{1, *}$, Nikita Saraswat $^{1}$, Rashmi Saxena Pal ${ }^{1}$, Ankita Wal $^{1}$ and Madhvi Chaubey ${ }^{1}$ \\ ${ }^{1}$ Department of Pharmacy, Pranveer Singh Insitute of Technology, Kanpur, India
}

\begin{abstract}
:
Background:

Curcumin is an active constituent of Curcuma longa, which belongs to Zingiberaceae family. It is derived from the Rhizome of a perennial plant having molecular formula $\mathrm{C}_{21} \mathrm{H}_{20} \mathrm{O}_{6}$ and chemically it is (1, 7- bis (4- hydroxy - 3 methoxyphenyl) - 1, 6 - heptadine - 3, 5 - diene), also known as diferuloylmethane. Curcumin has been extensively used as a herbal constituent for curing several diseases and is scientifically proven to show major effects as an anti-inflammatory agent.

Objective:

Inflammation is an important factor for numerous diseases including diabetes neuropathy, cancer, asthma, arthritis, and other diseases. Prophylaxis of inflammatory diseases through synthetic medications tends to have major toxicity and side effects on a large number of population. The foremost aim of this review paper is to assess the natural anti-inflammatory effect of curcumin, source, and mechanism of action, potential therapeutic effect and models associated. Additionally, this paper aims to scrutinize inflammation, sources of reactive oxygen species, and pathways of reactive oxygen species generation and potential side effects of curcumin.

\section{Methods:}

Selection of data has been done by studying the combination of research and review papers from different databases like PubMed, Medline and Web of science from the year 1985- 2018 by using search keywords like "curcumin", "anti-inflammatory", "ROS", "Curcuma longa", "medicinal uses of curcumin", "assessing parameters", "inflammation", "anti-oxidant"

Results:

On the basis of our interpretation, we have concluded that curcumin has potential therapeutic effects in different inflammatory diseases, it inhibits the inflammatory mediators, oxidation processes, and oxidative stress and has no severe toxicity on animals and humans.

\section{Conclusion:}

Oxidative stress is a major cause of inflammation and curcumin has a good potential for blocking it. Curcumin is also easily accessible herbal source and should be consumed in the form of food, antioxidant, anti-inflammatory agents and further observation should be done on its therapeutic parameters, risk factors, and toxicity studies and oral viability.
\end{abstract}

Keywords: Curcumin, Inflammation, ROS, Inflammasome, Interlukins, ENOS, NADPH, Myeloperoxidase (MPO), Peroxiredoxins (prx), NOX1-5, NLPR3.

Article History

Received: June 29, 2019

Revised: August 16, 2019

Accepted: August 27, 2019

\section{INTRODUCTION}

Curcumin (Curcuma longa) is a spice which belongs to Zingiberaceae family. It is derived from the Rhizome of a perennial plant [1]. It is low in molecular weight and chemically it

* Address correspondence to this author at Department of Pharmacy, Pranveer Singh Insitute of Technology, Kanpur, India; E-mail: pranaywal@gmail.com was initially characterized in 1910 with a molecular formula of $\mathrm{C} 21 \mathrm{H} 20 \mathrm{O} 6$ [2]. The remedial properties of this herb are known from ancient times. Chemically, curcumin is $(1,7$ - bis (4 hydroxy - 3 methoxyphenyl) - 1, 6 - heptadine - 3, 5 - diene), (Fig. 1) it is also known as diferuloylmethane as shown in (Fig. 1) Diferuloylmethane is one of the main polyphenyls found in this herb (Curcuma longa). In Asian Countries, Curcuma longa 
has extensively been used because it has a wide range of medicinal effect like antioxidant, anti-inflammatory [2], antimutagenic, anticancer and antimicrobial properties [3]. The active constituents which show medicinal property in this herb are curcuminoids present in Rhizome. So many studies have shown the pharmacokinetics of curcumin and proposed that it is poorly absorbed from the intestine. Studies have shown that oral absorption in Rats is poor approximately $75 \%$ of the constituents being excreted in the feces and in urine traces appeared while administration through i.p shows only $11 \%$ curcumin in bile, accounting poor absorption of curcumin through the intestine [4]. Curcumin acts as an antiinflammatory by inhibiting cyclooxygenase 2 (COX-2), inducible nitric oxide synthase (iNOs) and lipoxygenase (COX). INOs, LOX, and COX are key enzymes that mediate inflammatory processes. The inappropriate up-regulation of COX -2 and /or ins has found to be linked with the physiopathology of certain inflammatory disorders [2].
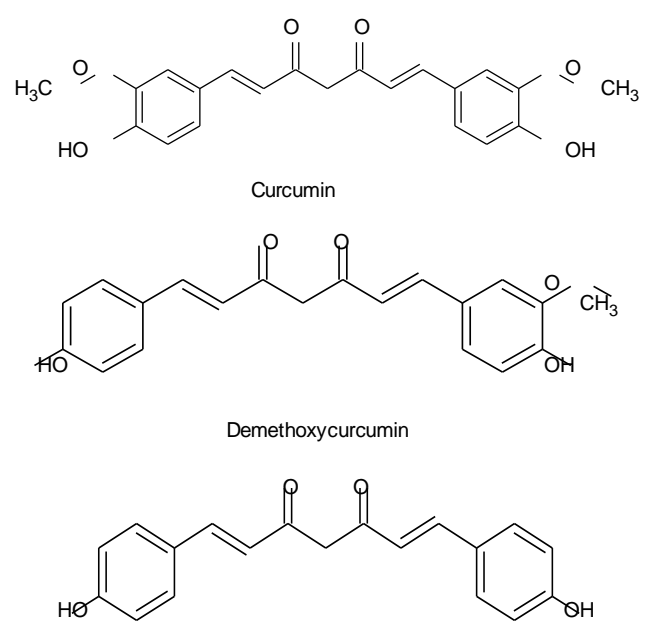

(1E,6E)-1,7-bis(4-hydroxyphenyl)hepta-1,6-diene-3,5-dione

Fig. (1). Chemical Structures of Curcumin, Demethoxycurcumin and Bisdemethoxycurcumin [3].

\subsection{Inflammation}

Historically, inflammation was characterized by some visual features like swelling, redness heat, pain, and loss of function, the former four features have been given by a Rome scientist Caelus. A short time ago, inflammation has been defined as "the series of transformations which happens in biological tissue after sudden laceration or trauma or abrasion if only the trauma or abrasion is not of such kind that at once it demolishes its morphology and endurance". However, previously inflammation was perceived as being a stage in the process of curing, from the $19^{\text {th }}$ century, inflammation was perceived as unwanted responses which can be destructive to the cell of the host [5]. In order to understand the antiinflammatory effect curcumin, firstly there is a need to understand the involvement or role of inflammation in pathological and physiological procedures like wound healing and infection. In order to cure an injury, signal transduction initiates and encourage the host to heal the tissue. The Neutrophils, monocytes, and eosinophils from the venous, plays a major role in this mechanism. Neutrophils perform a four-step procedure and which are believed to support the enlistment of these cells which are inflammatory to the site of injured tissue and to extracellular matrix (ECM), the endothelium and fibroblast proliferate and move for the rebuilding of the normal environment. Following steps involved are activation of (L-P- and E- selectin); immobilization of neutrophils and transmigration [6].

\section{MATERIALS AND METHODS}

A literature search was made on databases like Pubmed and Medline by using the keyword Curcumin, Antiinflammatory, ROS, inflammation and inflammasome. A combination of research and review paper was found and to get the most suitable article nonrelevant data were excluded. Selection of data has been done by studying the combination of research and review papers from different databases like PubMed, Core, Science3open, Directory of open access journals, EMBASE, Europe PMC, FSTA- Food Science and Technology, Nutrition, Google Scholar, HubMed, Merck Index, MedlinePluse, Indian citation index, Science Open, PubMed, Scopus, Semantic Scholar, World Wide Science, Shodhganga, Science Direct from year 1985- 2018 by using search keywords like curcumin, anti-inflammatory, ROS , curcuma longa, medicinal uses of curcumin, assessing parameters, inflammation, anti-oxidant.

\subsection{Inclusion and Exclusion of Databases}

500 publications were searched using keywords Curcumin, Anti-inflammatory, ROS , inflammation and inflammasome in databases PubMed, Core, Science3open, Directory of open access journals, EMBASE, Europe PMC, FSTA- Food Science and Technology, Nutrition, Google Scholar, HubMed, Merck Index, Medline Plus, Indian citation index, Science Open, PubMed, Scopus, Semantic Scholar, World Wide Science, Shodhganga, Science Direct from year 1985- 2018.

\subsection{Inclusion}

96 References were included because of the following reasons:

- Papers were relatable to the topic.

- Papers were published in the reputed journals.

- Papers were clear and were available in a suitable English language.

\subsection{Exclusion}

Rest papers were excluded because of the following reasons:

- Either papers were unclear or there were no proper conclusions.

- Few papers were not from the reputed journals and data was missing.

- Either explanatory images were not found in context to our topic or papers were not available in the English language. 


\subsection{Assessing Parameters Involved in Inflammation}

ROS source and regulation: ROS have moderately reduced oxygen metabolites, possessing high oxidizing potential. In low concentrations, they assist convoluted signaling functions but are injurious at a high concentration because oxidize cellular content like lipid and protein resulting in DNA damaging. ROS acts as signaling molecules and modulate cell growth, apoptosis, and adherence to neighbor cells, differentiation, and infirmity [7].

\subsection{Sources of ROS and their Regulation}

The major sources of ROS are Nicotinamide Adenine Dinu-cleotide Phosphate (NADPH) oxidase derived ROS in inflammation, mitochondria-derived Reactive Oxygen Species (ROS) in inflammation, xanthine oxidase derived Reactive Oxygen Species (ROS) in inflammation, and uncoupled NOS derived Reactive Oxygen Species (ROS) in inflammation and re-gulation of antioxidant defense system in inflammation (Fig. 2). Because of the prolonged generation of ROS, the chronic inflammatory disease progression takes place [8]. Superoxide anion $\left(\mathrm{O}_{2}{ }^{-}\right)$, hydrogen peroxide $\left(\mathrm{H}_{2} \mathrm{O}_{2}\right)$, hydroxyl radical $(\mathrm{OH})$, and hypochlorous acid (HOCL) are the biologically relevant ROS as per studies. ROS are also generated as a byproduct in cellular metabolic reactions taking place in mitochondria through electron transport chain (etc) and cytochrome P450 [9].

\subsection{ROS Production and Defense Mechanism in the Human Mitochondrial Cell}

The production of superoxide occurs by uncoupled endothelial nitric oxide synthase (eNOS), Nicotinamide Adenine Dinucleotide Phosphate (NADPH) oxidase and xanthine oxidase derived molecular reduction of oxygen. Superoxide $\mathrm{O}_{2}$ undergoes dismutation and form $\mathrm{H}_{2} \mathrm{O}_{2}$ by superoxide dismutase (SOD). $\mathrm{O}_{2}$ also reacts with nitric oxide and form peroxynitrite (ONOO), this is four times faster than $\mathrm{O}_{2}$ dismutation of $\mathrm{H}_{2} \mathrm{O}_{2}$. Further, highly reactive HOCL can form at inflammatory sites in the presence of Myeloperoxidase (MPO), this is indicated in neutrophils in ample amount. In the presence of $\mathrm{fe}^{+2}, \mathrm{H}_{2} \mathrm{O}_{2}$ can also form $\mathrm{OH}$ which is highly toxic this reaction is called Fenton's reaction. This reaction is catalyzed by peroxiredoxins (prx) or glutathione peroxidase (GPX). To detoxify H2O2 Prx uses thioredoxin (Trx) (Fig. 3) [7]. The summary of the whole process can be given by Haberweiss reaction and antioxidant reactions [9].

\section{Haber Weiss Reaction and Fenton s Reaction [9]}

$$
\begin{aligned}
& \mathrm{Fe}^{3+}+\mathrm{O}_{2} \mathrm{Fe}^{2+}+\mathrm{O}_{2} \\
& \mathrm{Fe}^{2+}+\mathrm{H}_{2} \mathrm{O}_{2} \mathrm{Fe}^{3+}+\mathrm{OH}+\mathrm{OH}
\end{aligned}
$$

\section{Antioxidants Reaction}

$$
\begin{aligned}
& 2 \mathrm{O}_{2}+2 \mathrm{H}^{+} \mathrm{H}_{2} \mathrm{O}_{2}+\mathrm{O}_{2} \\
& 2 \mathrm{H}_{2} \mathrm{O}_{2} \mathrm{H}_{2} \mathrm{O}+\mathrm{O}_{2} \\
& \mathrm{H}_{2} \mathrm{O}_{2}+2 \mathrm{GSH} 2 \mathrm{H}_{2} \mathrm{O}+\mathrm{GSSG} \\
& \mathrm{H}_{2} \mathrm{O}_{2}+\operatorname{Prx}(\mathrm{SH})_{2} 2 \mathrm{H}_{2} \mathrm{O}+\operatorname{PrxSS}
\end{aligned}
$$

$$
\operatorname{PrxSS}+\operatorname{Trx}(\mathrm{SH})_{2} \operatorname{Prx}(\mathrm{SH})_{2}+\operatorname{TrxSS}
$$

\subsection{Nicotinamide Adenine Dinucleotide Phosphate (NADPH) Oxidase}

NADPH oxidases, firstly recognized while inducing respiratory burst and bacterial killing in phagocytes [10] There are homologs of NADPH oxidase (NOX1-NOX5, Duox and 2), they are dissimilar in structures, their mechanism in different tissues [11]. The NADPH oxidase structure is defined in the Fig. (4). These homologs play a major role in vascular inflammation [7]. For activation of gp $91^{\text {phox }}$ two self-supporting events are needed, results in the association of regulatory proteins, present in the cytosol (p67 ${ }^{\text {phox }}, \mathrm{p} 22^{\text {phox, }}$ and $\mathrm{p} 40^{\text {phox }}$ ) along with flavocytochrome b558. The former event causes activation of Protein Kinase C (PKC) and AKT, resulting in phosphorylation of autoinhibitory zone (AIR) of $\mathrm{p} 47^{\text {phox }}$, hence violating inhibition through the autoinhibitory loop and allowing p47 ${ }^{\text {phox }}$ to attach with p22 ${ }^{\text {phox }}$. During second step GDP replacement with GTP occurs through (RhoGDI), encouraging its attachment with $\mathrm{p} 67^{\text {phox }}$, resulting in active complex formation. The hexagon in figure A indicates heme, NOX1, NOX4 and NOX5 in B to E, are NADPH oxidase homologs in which NOX1 to NOX4 have identical gp91 ${ }^{\text {phox }}$ core, NOX5 has intracellular $\mathrm{N}$ - terminal calcium binding domain, Duox 1 is also constructed at NOX5 structure of gp91 phox. NOX5 carries alpha-helical domain on $\mathrm{N}$ - terminal membrane. Through the assembly of Rac, NOXA1 and NOXO1 ROS generation occur by NOX1. There is no need for cytosolic subunit for production of ROS by NOX4 instead require $\mathrm{p} 22^{\text {phox }}$. ROS production through NOX5 and DUOX occur by calcium and p22 ${ }^{\text {phox }}$ subunit is not required [12 - 24].

\subsection{Mitochondrial-derived Reactive Oxygen Species in Inflammation}

An electron series forms a spatial arrangement in increasing order of their redox potential and get organized into four forms of complexes during mitochondrial etc. Electron transfer takes place between flavins $\left(\mathrm{FMN} \mathrm{H}_{2}\right.$ and $\left.\mathrm{FADH}_{2}\right)$ is shown by the arrows in those regions where complexes (I-IV) were formed, electron transfer also takes place between coenzyme Q $\left(\mathrm{Q}-\mathrm{QH}_{2}\right)$, iron-sulfur center $(\mathrm{Fe}-\mathrm{S})$, cytochrome (ca, a3 and c1) and molecular oxygen, all of these events lead to the formation of $\mathrm{H}_{2} \mathrm{O}$ Fig. (5). The major sites of ROS generation are two complexes, complex I and complex II, these complexes lead to the generation of reactive oxygen species [25-33].

\subsection{Activation of Inflammasome Through Reactive Oxygen Species (ROS)}

Raised reactive oxygen species generation within the cell either through mitochondrial electron chain transport or NADPH oxidase is recognized by Thioredoxin-Interacting Pgro-tein (TXNIP) and Trx complex, which directs the binding of NLRP3 with TXINP, followed by NLRP3 activation and asso-ciation of Asc and procaspase 1/12 proteins resulting in the construction of inflammasome (Fig. 6). Due to active NLRP3 inflammasome cleavage of interleukin-1 $\beta$ (IL-1) and pro-IL-18 to active IL-1 $\beta$ and IL 18 , released by inflammatory cells, 


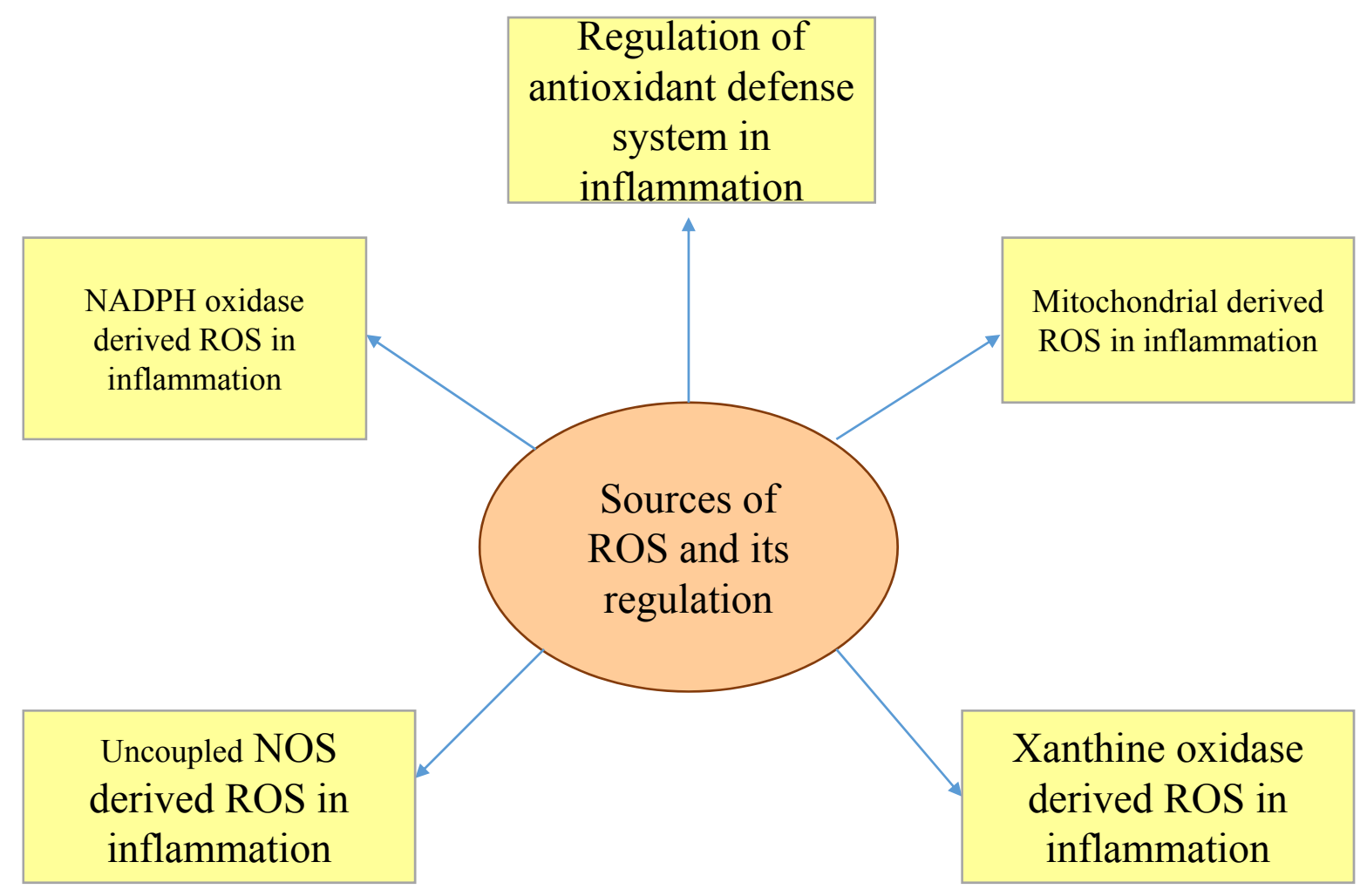

Fig. (2). Diagrammatic representation of the major sources of ROS production and their regulation via different mechanisms [9].

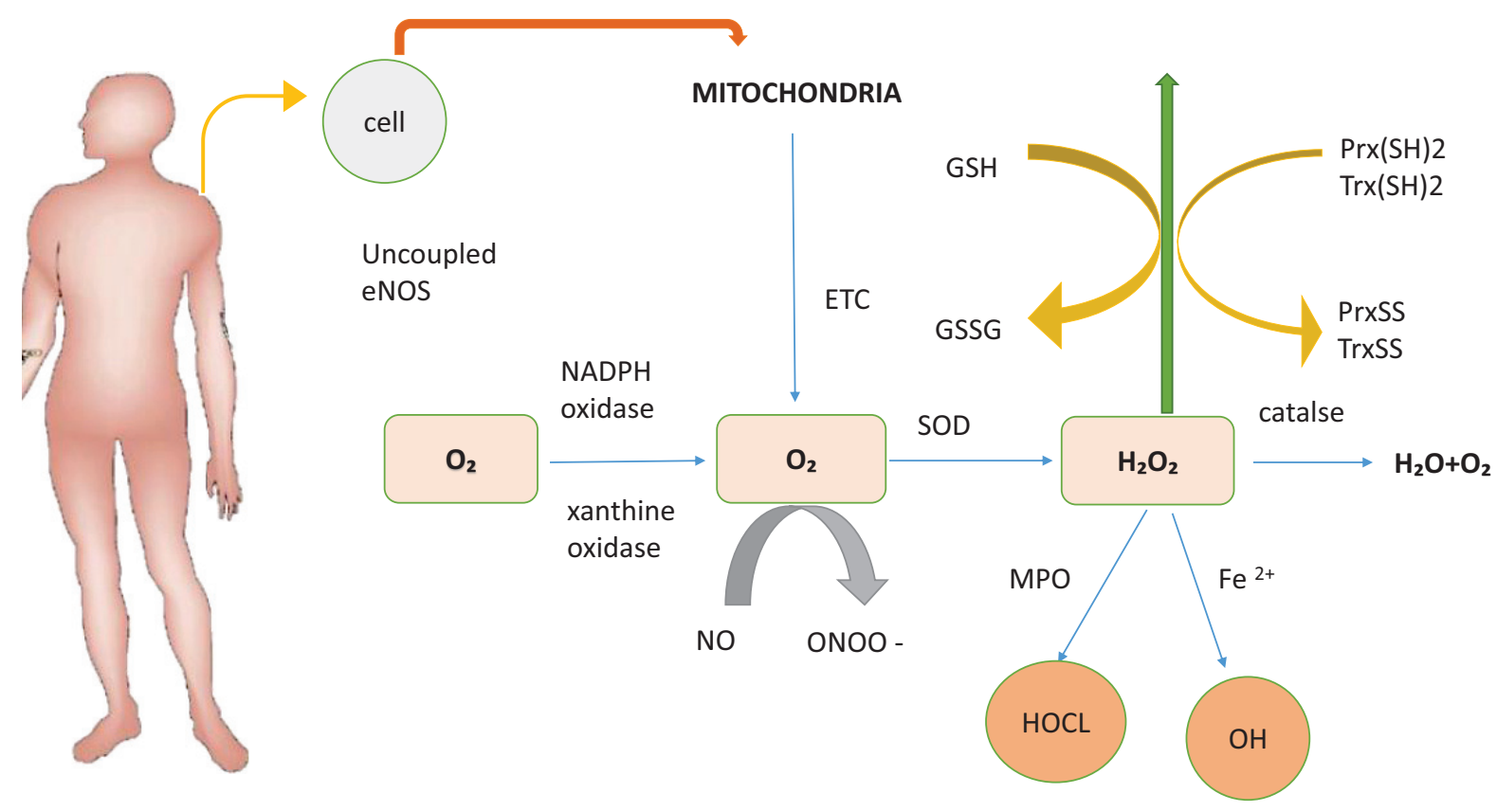

Human body 


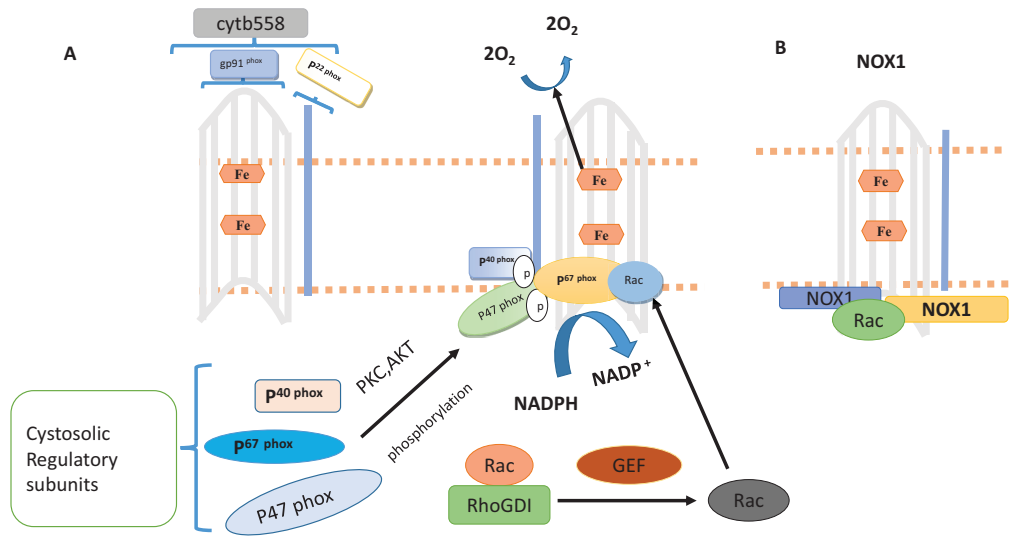

C

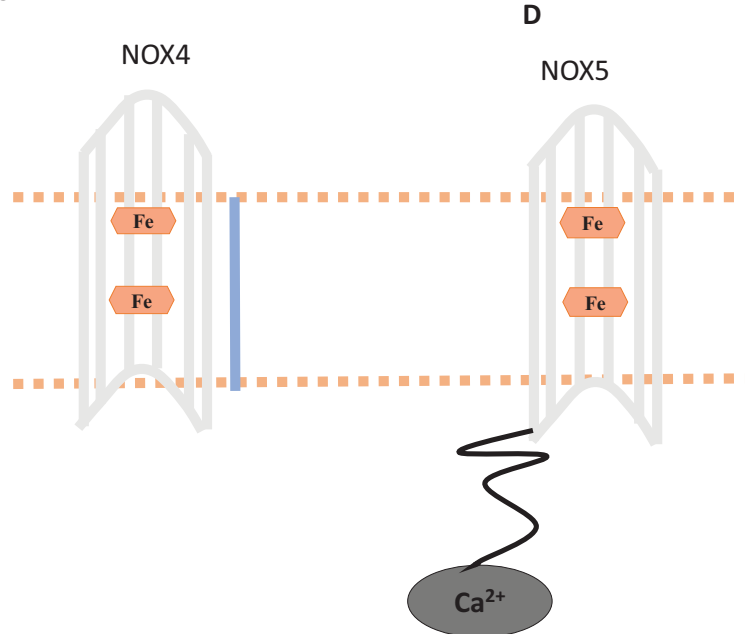

E Peroxidase domain

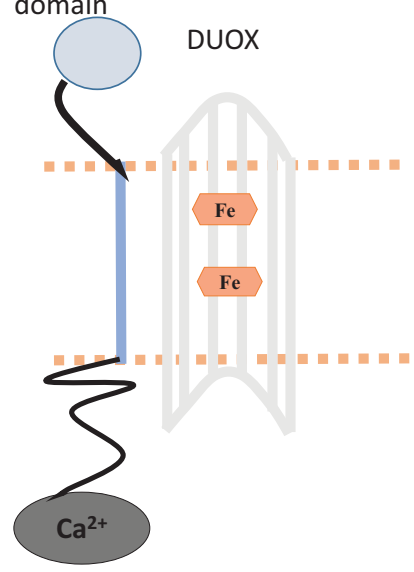

Fig. (4). Diagrammatic representation of NADPH oxidase activation, different homologs and their assembly [7].

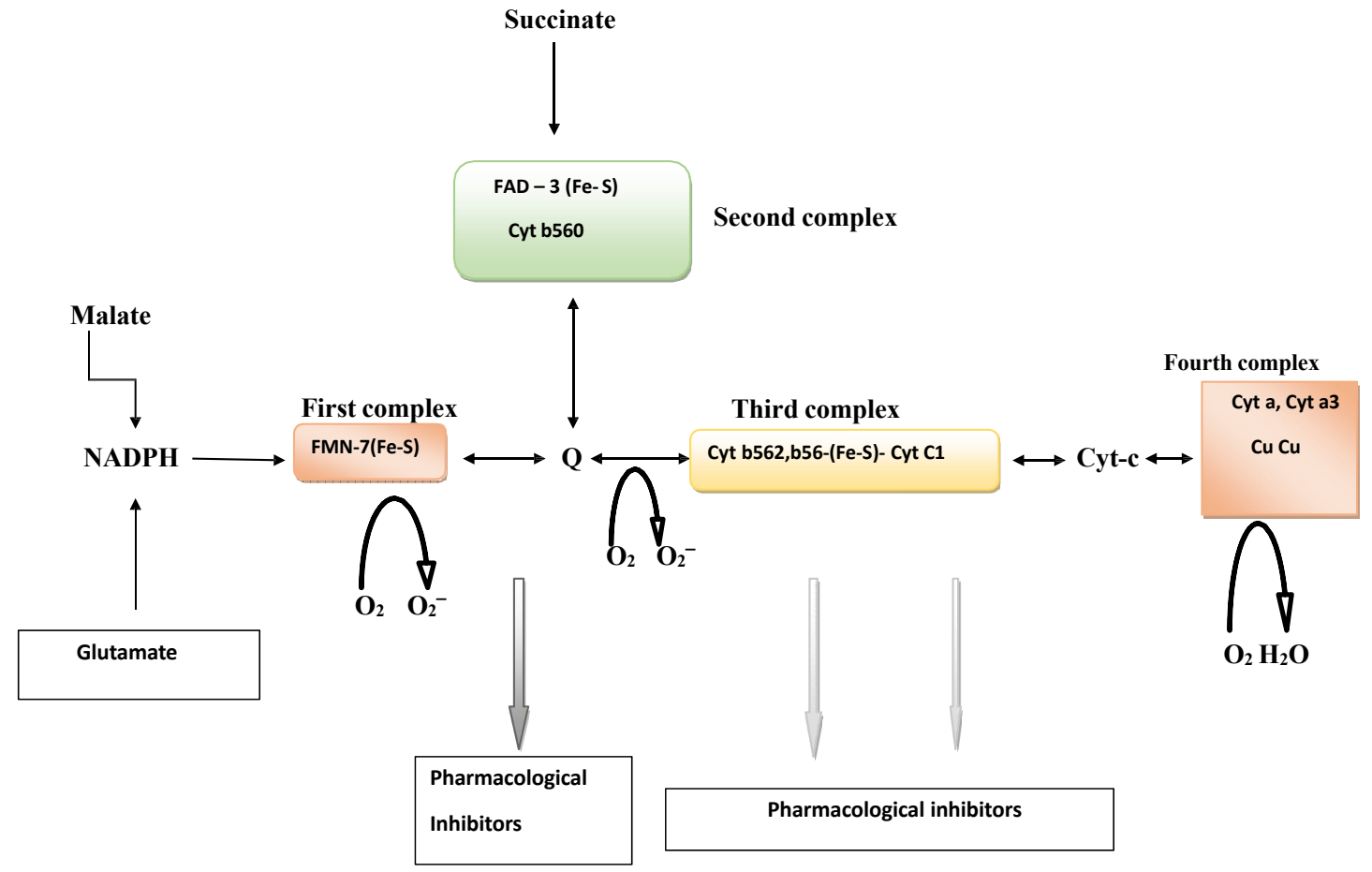

Fig. (5). Diagrammatic representation of the site of reactive oxygen species and mitochondrial electron transport chain reaction [5]. 
DAMP stands for danger associated molecular pattern; PAMP for the pathogen-associated molecular pattern; ASC stands for apoptosis-associated speck like protein [34 - 38].

\subsection{Uncoupled NOS- derived ROS in Inflammation}

eNOS enzyme has a homodimeric structure, it comprises of an oxygenase domain and a reductase. There is the binding site at eNOS interface for tetrahydrobiopterin $\left(\mathrm{BH}_{4}\right)$ which is a co-factor along with Larginine. Through monoxygenation, eNOS form L-citrulline by L-arginine and NO (by-product). During this process of reaction, oxidation of $\mathrm{BH}_{4}$ occurs and which forms tri hydro pterin radicals which further get protonated at the position $\mathrm{N} 5$ in the form of $\mathrm{BH}_{3} \mathrm{H}^{+}$. (Fig. 7).due to an elevation of peroxynitrite level an oxidative stress results and which further causes oxidation gives $\mathrm{BH} 2$ (biologically inactive) by $\mathrm{BH} 4$. $\mathrm{BH} 2$ cannot be taken back by the cell hence recycling of $\mathrm{BH} 2$ molecule gets interrupted and this leads to an uncoupled state of enzymes, reduction of oxygen to superoxide, block synthesis of NO [39 - 47].

\subsection{Mode of Action of Curcumin as an Anti-inflammatory Agent}

Oxidative stress is associated with many chronic diseases and its pathological conditions are firmly linked to inflammation, both of them are induced by one another. Inflammatory cells are also known to liberate numerous reactive species at its site which leads to oxidative stress. This manifests a link between inflammation and oxidative stress [48]. A number of reactive species can commence an intracellular signaling cascade that augments pro-inflammatory expression of genes. [49 - 51]. In so many chronic diseases like asthma, allergy, cancer, metabolic syndrome, multiple sclerosis, epilepsy, cardiovascular diseases, Parkinson's disease, cerebral injury, arthritis, psoriasis, diabetes, depression, obesity and Acquired Immune Deficiency Syndrome (AIDS) inflammation has been pointed out in the stage of all these disease progression [48]. The major inflammation mediator in various diseases is $\alpha$ (TNF- $\alpha$ ) tumor necrosis factor and it is regulated by nuclear factor (NF)- $\mathrm{kB}$. Among NF- $\kappa \mathrm{B}$ activator, TNF- $\alpha$ is the most influential and regulation of its expression is also done by NF- $\kappa \mathrm{B}$. Most of the cytokines stimulate NF- $\kappa B$, TNF- $\alpha$, disease-causing viruses; mechanical, chemical, physical, mental stress; curcumin blocks $\mathrm{NF}-\kappa \mathrm{B}$ activation by following different stimuli of inflammation, curcumin has been shown to subdue inflammation via separate mechanisms [48].

\section{CURCUMIN AS A POTENTIAL CURE FOR OTHER DISEASES}

\subsection{Neurodegenerative Diseases}

With aging, human brain tends to accumulate different metal ions like copper $(\mathrm{Cu})$, iron $(\mathrm{Fe})$ and zinc $(\mathrm{Zn})$. The human brain, however, has ample antioxidants that block the formation of ROS through Fenton reaction which involves metal ions reduction, boosting molecular oxygen [52]. As per curative point of view curcumin as a herbal source has been majorly shown to manifest antioxidant against major class of neurodegenerative diseases like neuropathic pain [53], Spongiform encephalopathies (Creutzfeld Jakob disease) [54], epilepsy [55], age-associated neurodegeneration [56], multiple sclerosis [57], cerebral injury [58], schizophrenia [59], Parkinson's disease [60], and depression [61]. Scientist Kim et al. (2001) found during his research that curcumin and few of its similar components like bisdemethoxycurcumin (BDMC) and demethoxycurcumin (DMC) reduce ROS generation in PC12 rat induced from Abeta- induced oxidative stress, and compounds were proved to show better antioxidant activity in comparison to alpha-tocopherol [62].

\subsection{Cardiovascular Diseases}

Through various reports, it has been found that inflammation contributes majorly to cardiovascular diseases [63]. One of which suggests that atherosclerosis is a result of damage of lipoproteins through oxidation i.e result of oxidative stress also damages blood vessels and membranes [64]. Second protolytic damage of one of elastin called median elastin is the cause of disease abdominal aortic aneurysms [65]. Many studies have concluded that curcumin protects the heart from cardiovascular disease. Srivastava et al. (1985) performed an experiment on animal to analyze the result of curcumin by inducing myocardial ischemia through ligation of left coronary artery, the heart was separated four hours earlier before the experiment and examined for myeloperoxidase(MPO), glutathione $(\mathrm{GSH})$, superoxide dismutase (SOD), lactate dehydrogenase (LDH), catalase (CAT). They found after the study that curcumin helps to maintain blood pressure, control ischemia and protect the heart from cardiovascular diseases [66].

\subsection{Diabetes}

Hyperglycemia is a disease which majorly affects kidney, liver, brain, heart and other body organs. Inflammation plays an important role in the pathogenesis of diabetes [67]. Curcumin can control the blood sugar levels, enhance an antioxidant property of pancreatic $\beta$ cells and also promotes stimulation of PPAR- $\gamma$ [68].

\subsection{Potential Therapeutic Effects of Curcumin in other Forms of Diseases}

Kobayashi et al. (1997) performed an experiment and examined the potential effect of curcumin on interleukins especially IL-5 and IL-2, IL-4 through lymphocytes in case of asthma caused by dust mites and others factors like (GM-CSF). $\mathrm{He}$ found that curcumin inhibited the production of (GM-CSF), IL-4, IL-5, and IL2 production, hence concluded that curcumin can suppress allergic responses by stimulating eosinophil and cytokines production [69]. Curcumin has been also found to be effective in various other diseases like renal ischemia [70], Scleroderma [71], Psoriasis [72], Acquired immunodeficiency disease (AIDS) [73], Rheumatoid Arthritis (RA) and other arthritis diseases [74] and cancer [75]. 


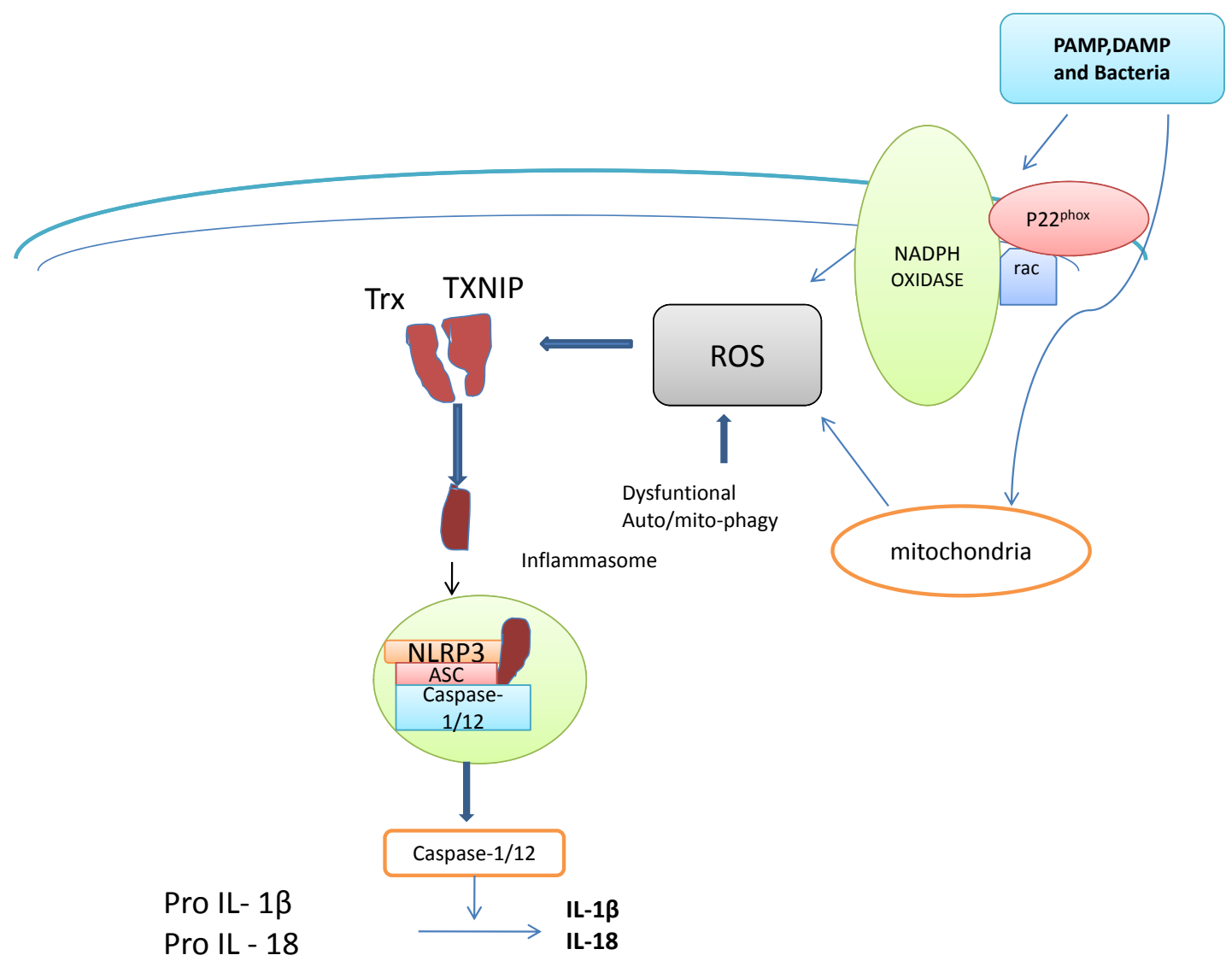

Fig. (6). Diagrammatic representation of activation of inflammasome through reactive oxygen species (ROS) [7].

a
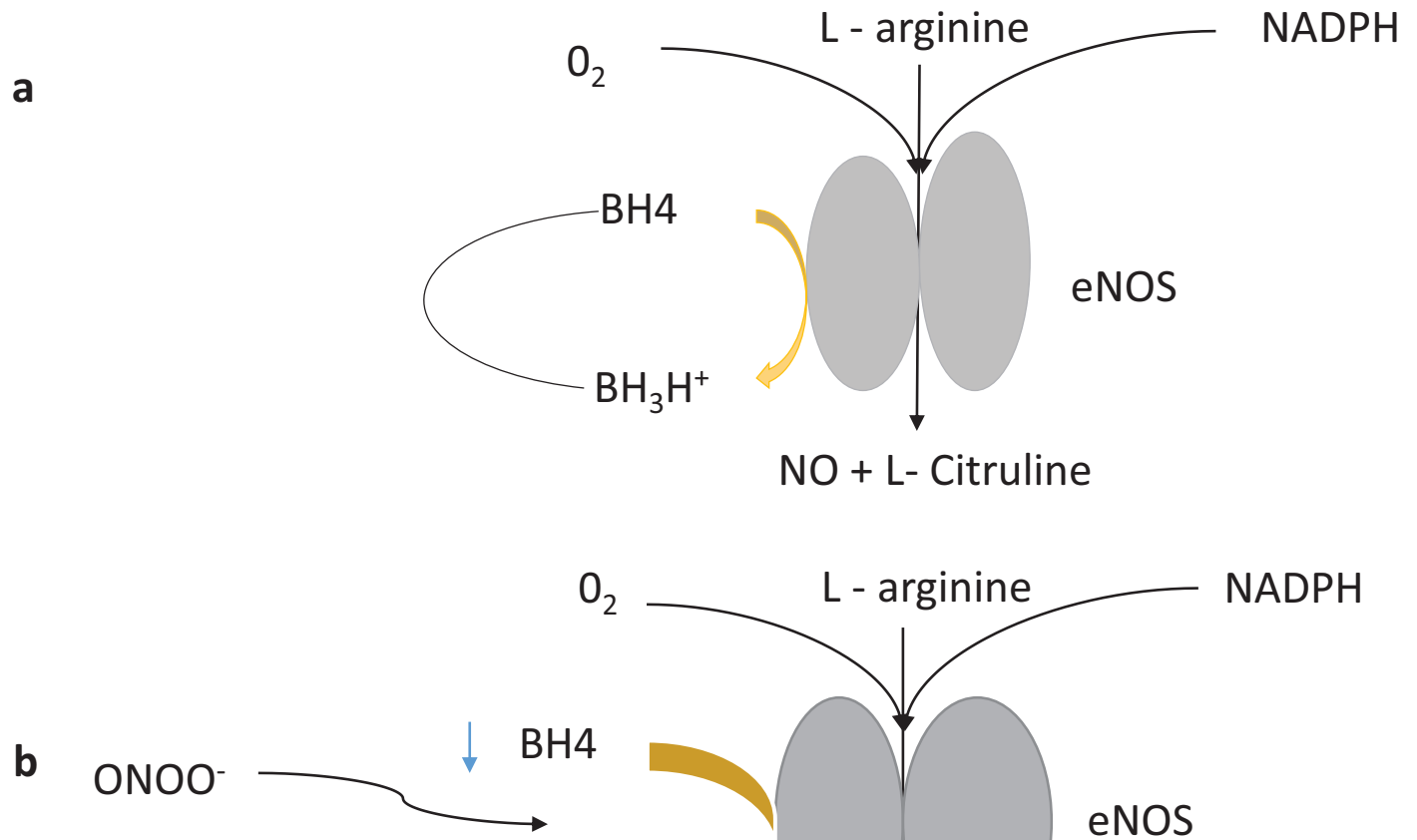

$\mathrm{O}_{2}$

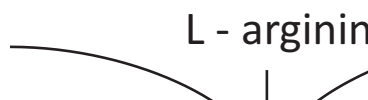

NADPH

$\mathrm{BH} 2$

ONOO

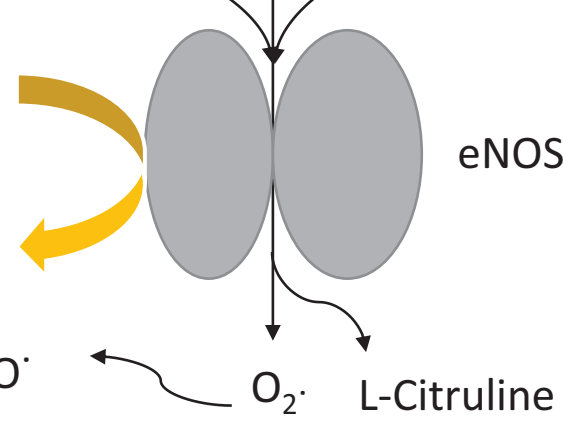

Fig. (7). Diagrammatic representation of reactive oxygen species generation through eNOS uncoupling by step a and step b [7]. 


\section{MODELS ASSOCIATED WITH ANTI- INFLAMMATORY PROPERTIES OF CURCUMIN}

\subsection{Edema and Inflammation}

Srimal et al. performed an experiment for edema and inflammation in mice by inducing carrageen. He found that at $50-200 \mathrm{mg} / \mathrm{kg}$ doses, curcumin shows the anti-inflammatory effect by reducing edema. With dose at $48 \mathrm{mg} / \mathrm{kg}$, about $50 \%$ anti-inflammatory effect was observed which is nearly equal to the effect of phenylbutazone and cortisone at the same dose [76].

\subsection{Ulcerative Colitis}

Studies have shown that curcumin suppresses mucosal damage in mice which was induced with colitis and at a regimen of $50 \mathrm{mg} / \mathrm{kg}$ of curcumin before 10 days of $1,4,6-$ trinitrobenzene sulphonic acid induction, indicated better colonic structure and reduction in neutrophil infiltration was observed, as well as inhibition in peroxidation of tissue and suppression of inflammation was observed [77].

\subsection{Rheumatoid Arthritis}

Wistar female rat was induced with the streptococcal cell for arthritis, a dose of $4 \mathrm{mg} / \mathrm{kg}$ per day and for continuous four days was given before inducing arthritis, as a result blocked the inflammation in joints in acute phase up to $75 \%$ and in chronic phase up to $68 \%$ [78].

\subsection{Pancreatitis}

Curcumin has been shown to reduce stimulation of NF- $\mathrm{KB}$ and blocking induction of mRNA of TNF- $\alpha$, interleukin 6 and iNOS, all these events take place in the pancreatic cell. It was found that in case one where pancreatitis was induced by cerulein and in the second case where pancreatitis was induced by ethanol, curcumin inhibited the inflammatory mediators, hence decreased the severity of the disease [79].

\subsection{The Potential Side Effect of Curcumin and Oral Bioavailability Enhancement}

According to FDA, curcumin is safe. Curcumin manifests many pharmacological effects but still, it is safe in humans and animals. Some studies were performed for the toxicity test of curcumin [80]. NTP has performed acute and chronic toxicity test in $\mathrm{B} 6 \mathrm{C} 3 \mathrm{~F} 1$ mice and $\mathrm{F} 344 / \mathrm{N}$ rats by using turmeric oleoresin at different doses and concluded that after observation, it was found that none of the animals died and no lesions and body toxicity was observed, only certain stains on fur and facial color alteration was found, no severe toxicity was pointed out [81]. A number of experimental reports have been showing the positive effect of curcumin along with chemotherapy [82 - 85]. The trials on human and animal study specifying the nontoxic and anti-inflammatory effect of curcumin have been summarized in Table 2 [91 - 95]. To improve oral bioavailability of curcumin, various chemical and technological methods are suggested till now. Microencapsulation which is polymer based has been found to be effective technique for the improvement of oral bioavailability of curcumin.

In vitro and ex vivo study has shown that there is good adhesive property in microparticles and because of this property oral bioavailability of curcumin has been found to be elevated [96].

\section{RESULTS}

On the basis of our interpretation, we have concluded that curcumin has potential therapeutic effects in different inflammatory diseases, it inhibits the inflammatory mediators, oxidation processes, oxidative stress and has no severe toxicity on animals and humans.

At normal physiology inflammation is the segment of the biological reaction of body cell or tissues towards dangerous or unwanted stimuli but at abnormal condition it leads to many severe diseases like pulmonary fibrosis, asthma, cancer, arthritis, diabetic neuropathy, inflammatory bowel disease and others. We have summarized scientific studies specifying Assessing parameters and inflammatory mediators associated with various inflammatory diseases in Table 1 [86 - 90].

\section{DISCUSSION}

There is a strong need to perform more studies on the therapeutic effect of curcumin in inflammatory diseases and as through studies, it was concluded that oral viability of curcumin is not so good, more experiments are required to enhance its viability through gut flora. During literature search we have found that polymer-based microencapsulation is useful in improving oral bioavailability of curcumin. We have reviewed a number of articles which explains the high therapeutic value and very low toxicity of curcumin in fatal diseases. Many researches are still in processes.

Table1. Assessing parameters and inflammatory mediators associated with various inflammatory diseases [ 86 - 89].

\begin{tabular}{|c|c|c|c|c|c|c|}
\hline \multirow[t]{2}{*}{$\begin{array}{l}\text { Scientist Reported } \\
\text { Data }\end{array}$} & \multirow{2}{*}{$\begin{array}{l}\text { Inflammatory } \\
\text { Mediators } \\
\text { and Assessing } \\
\text { Parameters }\end{array}$} & \multirow[t]{2}{*}{ Associated Diseases } & \multirow{2}{*}{$\begin{array}{c}\text { Study Conducted } \\
\text { on Animal / Cell } \\
\text { Culture }\end{array}$} & \multicolumn{2}{|c|}{$\begin{array}{c}\text { Study Conducted on } \\
\text { Human } \\
\end{array}$} & \multirow[t]{2}{*}{ Inference } \\
\hline & & & & \begin{tabular}{|c|} 
Duration of \\
Study (Year)
\end{tabular} & $\begin{array}{l}\text { Sample } \\
\text { Size }\end{array}$ & \\
\hline $\begin{array}{l}\text { Nadrowski } e t \\
\text { al.(2010) [86] }\end{array}$ & Interleukin 6(IL 6) & Atherosclerosis & NA & 2007-2011 & 4979 & $\begin{array}{l}\text { For systematic inflammation } \\
\text { IL-6 is important biomarker and } \\
\text { is responsible for } \\
\text { atherosclerosis. }\end{array}$ \\
\hline $\begin{array}{c}\text { Henry et al.(2008) } \\
{[87]}\end{array}$ & Interleukin -6 (IL- 6) & Depression & $\begin{array}{l}\text { BV-2 microglia } \\
\text { and } \\
\text { Male BALB/c } \\
\text { mice }\end{array}$ & NA & NA & $\begin{array}{l}\text { Decrease levels of IL-6 in blood } \\
\text { cause behavioral changes. }\end{array}$ \\
\hline
\end{tabular}


(Table 1) contd.....

\begin{tabular}{|c|c|c|c|c|c|c|}
\hline \multirow[t]{2}{*}{$\begin{array}{l}\text { Scientist Reported } \\
\text { Data }\end{array}$} & \multirow{2}{*}{$\begin{array}{l}\text { Inflammatory } \\
\text { Mediators } \\
\text { and Assessing } \\
\text { Parameters }\end{array}$} & \multirow{2}{*}{ Associated Diseases } & \multirow{2}{*}{$\begin{array}{c}\text { Study Conducted } \\
\text { on Animal / Cell } \\
\text { Culture }\end{array}$} & \multicolumn{2}{|c|}{$\begin{array}{c}\text { Study Conducted on } \\
\text { Human }\end{array}$} & \multirow[t]{2}{*}{ Inference } \\
\hline & & & & \begin{tabular}{|c|} 
Duration of \\
Study (Year)
\end{tabular} & $\begin{array}{l}\text { Sample } \\
\text { Size }\end{array}$ & \\
\hline $\begin{array}{c}\text { Zhang et al. (2014) } \\
{[88]}\end{array}$ & $\begin{array}{c}\text { NLRP3 } \\
\text { inflammasome }\end{array}$ & Depression & $\begin{array}{l}\text { Male BALB/c } \\
\text { mice }\end{array}$ & NA & NA & $\begin{array}{c}\text { NLRP3 inflammasome } \\
\text { is responsible for depressive } \\
\text { behaviors. }\end{array}$ \\
\hline $\begin{array}{l}\text { Grivennikov et al. } \\
\text { (2009) [89] }\end{array}$ & Interleukin -6 (IL- 6) & Lung cancer & Stat3F/F mice & NA & NA & $\begin{array}{l}\text { Destruction of IL-6 trans- } \\
\text { signaling delays growth of } \\
\text { tumor. }\end{array}$ \\
\hline Lin et al.(2017) [90] & Interleukin 6(IL 6) & $\begin{array}{l}\text { Hepatocellular } \\
\text { carcinoma }\end{array}$ & $\begin{array}{l}\text { Rag1-/- mice } \\
\text { And Rarres } 2-/- \\
\text { mice }\end{array}$ & & & $\begin{array}{l}\text { Elevated level of IL-6 leads to } \\
\text { progression of lung cancer. }\end{array}$ \\
\hline
\end{tabular}

Table 2. Summary of studies conducted on human and animal showing potent anti-inflammatory effect of curcumin as well as its nontoxic effect on human and animals [91 - 95].

\begin{tabular}{|c|c|c|c|c|c|c|c|c|}
\hline $\begin{array}{l}\text { Scientist } \\
\text { Conducted } \\
\text { Study }\end{array}$ & $\begin{array}{c}\text { Part of Curcuma } \\
\text { Longa Plant } \\
\text { Used }\end{array}$ & $\begin{array}{c}\text { Study } \\
\text { Conducted } \\
\text { on } \\
\text { (Animal) }\end{array}$ & \begin{tabular}{|c|} 
Study \\
Conducted \\
on Human \\
Sample size \\
\end{tabular} & $\begin{array}{l}\text { Trial } \\
\text { Phase }\end{array}$ & Models & Type of Study & Conclusion & Inference \\
\hline $\begin{array}{l}\text { Ashish } \\
\text { Shubhas et } \\
\text { al. }(2013) \\
\text { [91] }\end{array}$ & $\begin{array}{l}\text { Curcuminoids and } \\
\text { oil free aqueous } \\
\text { extract of } C \text {. longa } \\
\text { (COFAE) }\end{array}$ & $\begin{array}{c}\text { Albino } \\
\text { swiss Mice } \\
\text { and Albino } \\
\text { Wistar rats }\end{array}$ & NA & NA & $\begin{array}{c}\text { Xylene } \\
\text { induced ear } \\
\text { edema and } \\
\text { cotton } \\
\text { pallet } \\
\text { granuloma } \\
\text { model }\end{array}$ & Comparative. & $\begin{array}{c}\text { COFAE at dose level }(\mathrm{p}< \\
0.05) \text { reduce inflammation } \\
\text { in each animal model. On } \\
\text { comparative study the oil } \\
\text { free aqueous extract } \\
\text { showed better anti- } \\
\text { inflammatory effect as } \\
\text { compared to curcuminoids. }\end{array}$ & $\begin{array}{c}\text { The active } \\
\text { constituents of } \\
\text { curcumin has potent } \\
\text { anti-inflammatory } \\
\text { effect in its different } \\
\text { forms. }\end{array}$ \\
\hline $\begin{array}{l}\text { Chang et al. } \\
\text { (2001) [92] }\end{array}$ & $\begin{array}{l}8000 \mathrm{mg} \\
\text { curcumin } \\
\text { Per day }\end{array}$ & NA & 25 subjects & $\begin{array}{c}\text { Phase } \\
\text { I }\end{array}$ & NA & NA & $\begin{array}{l}\text { The study showed that } \\
\text { curcumin is not toxic to } \\
\text { humans when administered } \\
\text { for } 3 \text { months up to the dose } \\
\text { of } 8,000 \mathrm{mg} \text { /day (orally). }\end{array}$ & $\begin{array}{l}\text { Curcumin is nontoxic } \\
\text { to human. }\end{array}$ \\
\hline $\begin{array}{l}\text { Satoskar et } \\
\text { al.(1986) } \\
\text { [93] }\end{array}$ & $\begin{array}{l}\text { Curcumin }(1200 \\
\mathrm{mg} / \mathrm{d}) \text { and } \\
\text { phenylbutazone } \\
(300 \mathrm{mg} / \mathrm{d})\end{array}$ & NA & 45 subjects & NA & NA & $\begin{array}{c}\text { Comparative } \\
\text { Controlled trail. }\end{array}$ & $\begin{array}{c}\text { Controlled trial study was } \\
\text { conducted } \\
\text { (5-days) with } \\
45 \text { postsurgical patients } \\
\text { divided into groups } \\
\text { placebo, curcumin ( } 1200 \\
\text { mg/d), and } \\
\text { phenylbutazone ( } 300 \\
\text { mg/d). Phenylbutazone and } \\
\text { curcumin showed better } \\
\text { anti-inflammatory effect. }\end{array}$ & $\begin{array}{l}\text { Curcumin showed } \\
\text { better anti- } \\
\text { inflammatory effect. }\end{array}$ \\
\hline $\begin{array}{l}\text { Bundy Rafe } \\
\text { et al. }(2004) \\
{[94]}\end{array}$ & $\begin{array}{l}1 \text { tablet of } \\
\text { curcumin extract } \\
\text { per } 8^{\text {th }} \text { day }\end{array}$ & NA & $\begin{array}{c}500 \text { IBS } \\
\text { (selected) } \\
207 \text { subjects } \\
\text { (screened } \\
\text { for study) }\end{array}$ & $\begin{array}{c}\text { Phase } \\
\text { II }\end{array}$ & NA & $\begin{array}{l}\text { Partially } \\
\text { blinded, } \\
\text { randomized, } \\
\text { two-dose, pilot } \\
\text { study. }\end{array}$ & $\begin{array}{l}\text { The prevalence rate of } \\
\text { inflammatory bowel } \\
\text { syndrome found to be } \\
\text { declined up to } 41 \% \text { and } \\
57 \% \text { and further the } \\
\text { percentage declined to } \\
53 \%-60 \% \text { between base } \\
\text { line after treatment in both } \\
\text { groups. }\end{array}$ & $\begin{array}{l}\text { The anti- } \\
\text { inflammatory effect } \\
\text { of curcumin has been } \\
\text { seen in inflammatory } \\
\text { bowel syndrome. }\end{array}$ \\
\hline $\begin{array}{l}\text { Chandran } \\
\text { Binu et al. } \\
\text { (2012) [95] }\end{array}$ & $\begin{array}{l}\text { Curcumin (500 } \\
\text { mg) and } \\
\text { Diclofenac } \\
\text { Sodium }(50 \mathrm{mg})\end{array}$ & NA & 45 & $\begin{array}{c}\text { Phase } \\
\text { II }\end{array}$ & NA & $\begin{array}{l}\text { Randomized, } \\
\text { single-blinded, } \\
\text { pilot study. }\end{array}$ & $\begin{array}{l}\text { Patients were randomly } \\
\text { allocated in } 1: 1: 1 \text { ratio for } \\
\text { administration of curcumin } \\
500 \mathrm{mg} \text { (Group I) or } \\
\text { curcumin } 500 \mathrm{mg}+ \\
\text { diclofenac sodium } 50 \mathrm{mg} \\
\text { (Group II), or diclofenac } \\
\text { sodium } 50 \mathrm{mg} \text { (Group III) } \\
\text { over a period of } 8 \text { weeks. }\end{array}$ & $\begin{array}{l}\text { Curcumin showed } \\
\text { better anti- } \\
\text { inflammatory effect } \\
\text { and reduced pain } \\
\text { also. }\end{array}$ \\
\hline
\end{tabular}




\section{CONCLUSION}

Curcumin (Curcuma longa) belongs to Zingiberaceae family, is a perennial plant, having curcuminoids as the major active constituent. It exhibits a wide range of therapeutic property like anti-inflammatory, antioxidants, antimutagenic, anticancer and antimicrobial property.

Curcumin acts as an anti-inflammatory by inhibiting cyclooxygenase 2 (COX-2), inducible nitric oxide synthase (ins) and lipoxygenase (COX). INOs, LOX, and COX are key enzymes that mediate inflammatory processes. The inappropriate up-regulation of COX -2 and /or ins has found to be linked with the physiopathology of certain inflammatory diseases. Therefore, consumption of curcumin in daily life can protect from inflammation and oxidation induced processes and can contribute to a healthy lifestyle.

Most of the studies have found that cucumin has the potential for curing inflammatory diseases as it blocks the mechanism of reactive oxygen species generation via inhibiting oxidative stress. Curcumin has prominent effect on inflammatory mediators like cytokines as a result of which it blocks the oxidation process in mitochondria of the cell and reduces inflammation.

Curcumin should be considered for formulations. It has no severe toxicity as per studies, no carcinogenesis lesions were found during toxicity studies, although it has the potential to act as anticancer agent in various types of cancer induced through inflammation. The mechanisms of actions and its antiinflammatory parameters must be thoroughly evaluated for future researches to design new formulations for treatment of various life-threatening diseases.

\section{LIST OF ABBREVIATIONS}

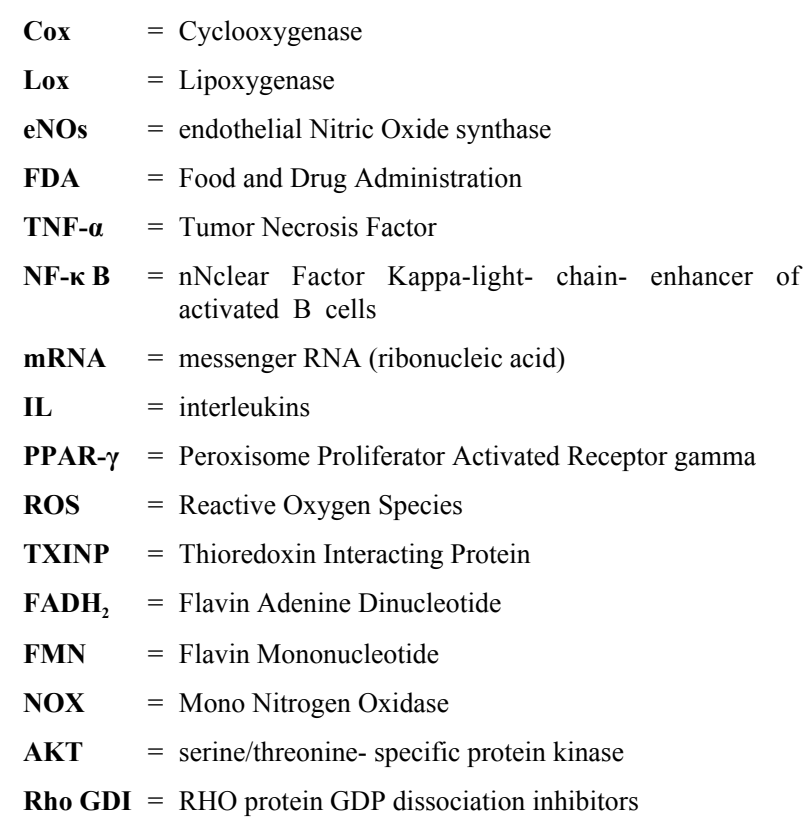

\section{CONSENT FOR PUBLICATION}

Not applicable.

\section{FUNDING}

None.

\section{CONFLICT OF INTEREST}

The authors declare no conflict of interest, financial or otherwise.

\section{ACKNOWLEDGEMENTS}

We are genuinely thankful to the department of Pharmacy, Pranveer Singh Institute of Technology, Kanpur, Uttar Pradesh, India, for immensely guiding us and helping while writing this review article.

\section{REFERENCES}

[1] Julie S, Jurenka MT. Anti-inflammatory properties of curcumin, a major constituent of Curcuma longa: A review of preclinical and clinical research. Altern Med Rev 2009; 14(2): 141-53. [PMID: 19594223]

[2] Lestari ML, Indrayanto G. Curcumin. Profiles Drug Subst Excip Relat Methodol 2014; 39: 113-204.

[http://dx.doi.org/10.1016/B978-0-12-800173-8.00003-9] [PMID: 24794906]

[3] Menon VP, Sudheer AR. Antioxidant and anti-inflammatory properties of curcumin. Adv Exp Med Biol 2007; 595: 105-25. [http://dx.doi.org/10.1007/978-0-387-46401-5_3] [PMID: 17569207]

[4] Maheshwari RK, Singh AK, Gaddipati J, Srimal RC. Multiple biological activities of curcumin: A short review. Life Sci 2006; 78(18): 2081-7.

[http://dx.doi.org/10.1016/j.lfs.2005.12.007] [PMID: 16413584]

[5] Neville AP, Cliff JW, Ian A. The journal of inflammation license. BioMed Central Ltd 2004; 1 : 1.

[6] Coussens LM, Werb Z. Inflammation and cancer. Nature 2002; 420(6917): 860-7.

[http://dx.doi.org/10.1038/nature01322] [PMID: 12490959]

[7] Mittal M, Siddiqui MR, Tran K, Reddy SP, Malik AB. Reactive oxygen species in inflammation and tissue injury. Antioxid Redox Signal 2014; 20(7): 1126-67.

[http://dx.doi.org/10.1089/ars.2012.5149] [PMID: 23991888]

[8] Griffith B, Pendyala S, Hecker L, Lee PJ, Natarajan V, Thannickal VJ. NOX enzymes and pulmonary disease. Antioxid Redox Signal 2009; 11(10): 2505-16.

[http://dx.doi.org/10.1089/ars.2009.2599] [PMID: 19331546]

[9] Thannickal VJ, Fanburg BL. Reactive oxygen species in cell signaling. Am J Physiol Lung Cell Mol Physiol 2000; 279(6): L1005-28. [http://dx.doi.org/10.1152/ajplung.2000.279.6.L1005] [PMID: 11076791]

[10] Lao CD, Ruffin MT IV, Normolle D, et al. Dose escalation of a curcuminoid formulation. BMC Complement Altern Med 2006; 6: 10. [http://dx.doi.org/10.1186/1472-6882-6-10] [PMID: 16545122]

[11] Krause KH. Aging: A revisited theory based on free radicals generated by NOX family NADPH oxidases. Exp Gerontol 2007; 42(4): 256-62. [http://dx.doi.org/10.1016/j.exger.2006.10.011] [PMID: 17126513]

[12] Sbarra AJ, Karnovsky ML. The biochemical basis of phagocytosis. I. Metabolic changes during the ingestion of particles by polymorphonuclear leukocytes. J Biol Chem 1959; 234(6): 1355-62. [PMID: 13654378]

[13] Basuroy S, Bhattacharya S, Leffler CW, Parfenova H. Nox4 NADPH oxidase mediates oxidative stress and apoptosis caused by TNF-alpha in cerebral vascular endothelial cells. Am J Physiol Cell Physiol 2009; 296(3): C422-32.

[http://dx.doi.org/10.1152/ajpcell.00381.2008] [PMID: 19118162]

[14] Lambeth JD. NOX enzymes and the biology of reactive oxygen. Nat Rev Immunol 2004; 4(3): 181-9.

[http://dx.doi.org/10.1038/nri1312] [PMID: 15039755]

[15] Pendyala S, Usatyuk PV, Gorshkova IA, Garcia JG, Natarajan V. Regulation of NADPH oxidase in vascular endothelium: The role of phospholipases, protein kinases, and cytoskeletal proteins. Antioxid Redox Signal 2009; 11(4): 841-60.

[http://dx.doi.org/10.1089/ars.2008.2231] [PMID: 18828698]

[16] Kawahara T, Kohjima M, Kuwano Y, et al. Helicobacter pylori lipopolysaccharide activates Rac1 and transcription of NADPH 
oxidase Nox 1 and its organizer NOXO1 in guinea pig gastric mucosal cells. Am J Physiol Cell Physiol 2005; 288(2): C450-7.

[http://dx.doi.org/10.1152/ajpcell.00319.2004] [PMID: 15469954]

[17] Dang PM, Dewas C, Gaudry M, et al. Priming of human neutrophil respiratory burst by granulocyte/macrophage colony-stimulating factor (GM-CSF) involves partial phosphorylation of p47(phox). J Biol Chem 1999; 274(29): 20704-8.

[http://dx.doi.org/10.1074/jbc.274.29.20704] [PMID: 10400704]

[18] Martinon F, Mayor A, Tschopp J. The inflammasomes: Guardians of the body. Annu Rev Immunol 2009; 27: 229-65.

[http://dx.doi.org/10.1146/annurev.immunol.021908.132715] [PMID: 19302040]

[19] Dang PM, Stensballe A, Boussetta T, et al. A specific p47phox -serine phosphorylated by convergent MAPKs mediates neutrophil NADPH oxidase priming at inflammatory sites. J Clin Invest 2006; 116(7): 2033-43.

[http://dx.doi.org/10.1172/JCI27544] [PMID: 16778989]

[20] DeLeo FR, Renee J, McCormick S, et al. Neutrophils exposed to bacterial lipopolysaccharide upregulate NADPH oxidase assembly. J Clin Invest 1998; 101(2): 455-63.

[http://dx.doi.org/10.1172/JCI949] [PMID: 9435318]

[21] Dewas C, Dang PM, Gougerot-Pocidalo MA, El-Benna J. TNF-alpha induces phosphorylation of $\mathrm{p} 47$ (phox) in human neutrophils: Partial phosphorylation of $\mathrm{p} 47 \mathrm{phox}$ is a common event of priming of human neutrophils by TNF-alpha and granulocyte-macrophage colonystimulating factor. J Immunol 2003; 171(8): 4392-8. [http://dx.doi.org/10.4049/jimmunol.171.8.4392] [PMID: 14530365]

[22] Ambasta RK, Kumar P, Griendling KK, Schmidt HH, Busse R, Brandes RP. Direct interaction of the novel Nox proteins with $\mathrm{p} 22$ phox is required for the formation of a functionally active NADPH oxidase. J Biol Chem 2004; 279(44): 45935-41.

[http://dx.doi.org/10.1074/jbc.M406486200] [PMID: 15322091]

[23] Gao XP, Standiford TJ, Rahman A, et al. Role of NADPH oxidase in the mechanism of lung neutrophil sequestration and microvessel injury induced by Gram-negative sepsis: Studies in p47phox-/- and gp91phox-/- mice. J Immunol 2002; 168(8): 3974-82. [http://dx.doi.org/10.4049/jimmunol.168.8.3974] [PMID: 11937554]

[24] Bánfi B, Clark RA, Steger K, Krause KH. Two novel proteins activate superoxide generation by the NADPH oxidase NOX1. J Biol Chem 2003; 278(6): 3510-3.

[http://dx.doi.org/10.1074/jbc.C200613200] [PMID: 12473664]

[25] Handy DE, Loscalzo J. Redox regulation of mitochondrial function. Antioxid Redox Signal 2012; 16(11): 1323-67.

[http://dx.doi.org/10.1089/ars.2011.4123] [PMID: 22146081]

[26] O'Malley Y, Fink BD, Ross NC, Prisinzano TE, Sivitz WI. Reactive oxygen and targeted antioxidant administration in endothelial cell mitochondria. J Biol Chem 2006; 281(52): 39766-75.

[http://dx.doi.org/10.1074/jbc.M608268200] [PMID: 17060316]

[27] Chandel NS, Trzyna WC, McClintock DS, Schumacker PT. Role of oxidants in NF-kappa B activation and TNF-alpha gene transcription induced by hypoxia and endotoxin. J Immunol 2000; 165(2): 1013-21. [http://dx.doi.org/10.4049/jimmunol.165.2.1013] [PMID: 10878378]

[28] Mansfield KD, Guzy RD, Pan Y, et al. Mitochondrial dysfunction resulting from loss of cytochrome $\mathrm{c}$ impairs cellular oxygen sensing and hypoxic HIF-alpha activation. Cell Metab 2005; 1(6): 393-9. [http://dx.doi.org/10.1016/j.cmet.2005.05.003] [PMID: 16054088]

[29] Wang D, Malo D, Hekimi S. Elevated mitochondrial reactive oxygen species generation affects the immune response via hypoxia-inducible factor-1alpha in long-lived Mclk1+/- mouse mutants. J Immunol 2010; 184(2): 582-90.

[http://dx.doi.org/10.4049/jimmunol.0902352] [PMID: 20007531]

[30] Ichimura H, Parthasarathi K, Quadri S, Issekutz AC, Bhattacharya J. Mechano-oxidative coupling by mitochondria induces proinflammatory responses in lung venular capillaries. J Clin Invest 2003; 111(5): 691-9. [http://dx.doi.org/10.1172/JCI17271] [PMID: 12618523]

[31] Naik E, Dixit VM. Mitochondrial reactive oxygen species drive proinflammatory cytokine production. J Exp Med 2011; 208(3): 417-20.

[http://dx.doi.org/10.1084/jem.20110367] [PMID: 21357740]

[32] Goto H, Nishikawa T, Sonoda K, et al. Endothelial MnSOD overexpression prevents retinal VEGF expression in diabetic mice. Biochem Biophys Res Commun 2008; 366(3): 814-20. [http://dx.doi.org/10.1016/j.bbrc.2007.12.041] [PMID: 18083119]

[33] Nishikawa T, Araki E. Impact of mitochondrial ROS production in the pathogenesis of diabetes mellitus and its complications. Antioxid Redox Signal 2007; 9(3): 343-53. [http://dx.doi.org/10.1089/ars.2006.1458] [PMID: 17184177]

[34] Sutterwala FS, Ogura Y, Szczepanik M, et al. Critical role for NALP3/CIAS1/Cryopyrin in innate and adaptive immunity through its regulation of caspase-1. Immunity 2006; 24(3): 317-27.

[http://dx.doi.org/10.1016/j.immuni.2006.02.004] [PMID: 16546100]

[35] Zhou R, Tardivel A, Thorens B, Choi I, Tschopp J. Thioredoxininteracting protein links oxidative stress to inflammasome activation. Nat Immunol 2010; 11(2): 136-40.

[http://dx.doi.org/10.1038/ni.1831] [PMID: 20023662]

[36] Zhou R, Yazdi AS, Menu P, Tschopp J. A role for mitochondria in NLRP3 inflammasome activation. Nature 2011; 469(7329): 221-5.

[http://dx.doi.org/10.1038/nature09663] [PMID: 21124315]

[37] Nakahira K, Haspel JA, Rathinam VA, et al. Autophagy proteins regulate innate immune responses by inhibiting the release of mitochondrial DNA mediated by the NALP3 inflammasome. Nat Immunol 2011; 12(3): 222-30.

[http://dx.doi.org/10.1038/ni.1980] [PMID: 21151103]

[38] Saitoh T, Fujita N, Jang MH, et al. Loss of the autophagy protein Atg16L1 enhances endotoxin-induced IL-1beta production. Nature 2008; 456(7219): 264-8.

[http://dx.doi.org/10.1038/nature07383] [PMID: 18849965]

[39] Förstermann U, Münzel T. Endothelial nitric oxide synthase in vascular disease: From marvel to menace. Circulation 2006; 113(13): 1708-14.

[http://dx.doi.org/10.1161/CIRCULATIONAHA.105.602532] [PMID: 16585403]

[40] Dal Secco D, Moreira AP, Freitas A, et al. Nitric oxide inhibits neutrophil migration by a mechanism dependent on ICAM-1: Role of soluble guanylate cyclase. Nitric Oxide 2006; 15(1): 77-86.

[http://dx.doi.org/10.1016/j.niox.2006.02.004] [PMID: 16621629]

[41] Alp NJ, Channon KM. Regulation of endothelial nitric oxide synthase by tetrahydrobiopterin in vascular disease. Arterioscler Thromb Vasc Biol 2004; 24(3): 413-20.

[http://dx.doi.org/10.1161/01.ATV.0000110785.96039.f6] [PMID: 14656731]

[42] Laursen JB, Somers M, Kurz S, et al. Endothelial regulation of vasomotion in apoE-deficient mice: Implications for interactions between peroxynitrite and tetrahydrobiopterin. Circulation 2001; 103(9): $1282-8$.

[http://dx.doi.org/10.1161/01.CIR.103.9.1282] [PMID: 11238274]

[43] Ozaki M, Kawashima S, Yamashita T, et al. Overexpression of endothelial nitric oxide synthase accelerates atherosclerotic lesion formation in apoE-deficient mice. J Clin Invest 2002; 110(3): 331-40. [http://dx.doi.org/10.1172/JCI0215215] [PMID: 12163452]

[44] Sydow K, Münzel T. ADMA and oxidative stress. Atheroscler Suppl 2003; 4(4): 41-51.

[http://dx.doi.org/10.1016/S1567-5688(03)00033-3] 14664902]

[45] Böger RH, Sydow K, Borlak J, et al. LDL cholesterol upregulates synthesis of asymmetrical dimethylarginine in human endothelial cells: Involvement of S-adenosylmethionine-dependent methyltransferases. Circ Res 2000; 87(2): 99-105.

[http://dx.doi.org/10.1161/01.RES.87.2.99] [PMID: 10903992]

[46] Sharma S, Smith A, Kumar S, et al. Mechanisms of nitric oxide synthase uncoupling in endotoxin-induced acute lung injury: Role of asymmetric dimethylarginine. Vascul Pharmacol 2010; 52(5-6): 182-90.

[http://dx.doi.org/10.1016/j.vph.2009.11.010] [PMID: 19962451]

[47] O'Dwyer MJ, Dempsey F, Crowley V, Kelleher DP, McManus R, Ryan T. Septic shock is correlated with asymmetrical dimethyl arginine levels, which may be influenced by a polymorphism in the dimethylarginine dimethylaminohydrolase II gene: A prospective observational study. Crit Care 2006; 10(5): R139.

[http://dx.doi.org/10.1186/cc5053] [PMID: 17002794]

[48] Biswas SK. Does the Interdependence between Oxidative Stress and Inflammation Explain the Antioxidant Paradox? Oxid Med Cell Longev 2016; 20165698931

[http://dx.doi.org/10.1155/2016/5698931] [PMID: 26881031]

[49] Panahi Y, Hosseini MS, Khalili N, et al. Effects of curcumin on serum cytokine concentrations in subjects with metabolic syndrome: A posthoc analysis of a randomized controlled trial. Biomed Pharmacother 2016; 82: 578-82.

[http://dx.doi.org/10.1016/j.biopha.2016.05.037] [PMID: 27470399]

[50] Susan J. Hewlings, Douglas S Kalman. Curcumin: A Review of Its Effects on Human Health.mdpi Published: 22 October. 2017.

[51] Recio MC, Andujar I, Rios JL. Anti-inflammatory agents from plants: Progress and potential. Curr Med Chem 2012; 19(14): 2088-103. 
[http://dx.doi.org/10.2174/092986712800229069] [PMID: 22414101]

[52] Smith DG, Cappai R, Barnham KJ. The redox chemistry of the Alzheimer's disease amyloid beta peptide. Biochim Biophys Acta 2007; 1768(8): 1976-90.

[http://dx.doi.org/10.1016/j.bbamem.2007.02.002] [PMID: 17433250]

[53] Sharma S, Kulkarni SK, Agrewala JN, Chopra K. Curcumin attenuates thermal hyperalgesia in a diabetic mouse model of neuropathic pain. Eur J Pharmacol 2006; 536(3): 256-61.

[http://dx.doi.org/10.1016/j.ejphar.2006.03.006] [PMID: 16584726]

[54] Hafner-Bratkovic I, Gaspersic J, Smid LM, Bresjanac M, Jerala R. Curcumin binds to the alpha-helical intermediate and to the amyloid form of prion protein - a new mechanism for the inhibition of $\operatorname{PrP}(\mathrm{Sc})$ accumulation. J Neurochem 2008; 104(6): 1553-64

[http://dx.doi.org/10.1111/j.1471-4159.2007.05105.x]

[PMID: 17996023]

[55] Sumanont Y, Murakami Y, Tohda M, Vajragupta O, Watanabe H, Matsumoto K. Prevention of kainic acid-induced changes in nitric oxide level and neuronal cell damage in the rat hippocampus by manganese complexes of curcumin and diacetylcurcumin. Life Sci 2006; 78(16): 1884-91.

[http://dx.doi.org/10.1016/j.lfs.2005.08.028] [PMID: 16266725]

[56] Calabrese V, Scapagnini G, Colombrita C, et al. Redox regulation of heat shock protein expression in aging and neurodegenerative disorders associated with oxidative stress: A nutritional approach. Amino Acids 2003; 25(3-4): 437-44.

[http://dx.doi.org/10.1007/s00726-003-0048-2] [PMID: 14661103]

[57] Natarajan C, Bright JJ. Curcumin inhibits experimental allergic encephalomyelitis by blocking IL-12 signaling through Janus kinaseSTAT pathway in T lymphocytes. J Immunol 2002; 168(12): 6506-13. [http://dx.doi.org/10.4049/jimmunol.168.12.6506] [PMID: 12055272]

[58] Ghoneim AI, Abdel-Naim AB, Khalifa AE, El-Denshary ES. Protective effects of curcumin against ischaemia/reperfusion insult in rat forebrain. Pharmacol Res 2002; 46(3): 273-9.

[http://dx.doi.org/10.1016/S1043-6618(02)00123-8]

[PMID 12220971]

[59] Bishnoi M, Chopra K, Kulkarni SK. Protective effect of Curcumin, the active principle of turmeric (Curcuma longa) in haloperidol-induced orofacial dyskinesia and associated behavioural, biochemical and neurochemical changes in rat brain. Pharmacol Biochem Behav 2008; 88(4): 511-22.

[http://dx.doi.org/10.1016/j.pbb.2007.10.009] [PMID: 18022680]

[60] Zbarsky V, Datla KP, Parkar S, Rai DK, Aruoma OI, Dexter DT. Neuroprotective properties of the natural phenolic antioxidants curcumin and naringenin but not quercetin and fisetin in a 6-OHDA model of Parkinson's disease. Free Radic Res 2005; 39(10): 1119-25. [http://dx.doi.org/10.1080/10715760500233113] [PMID: 16298737]

[61] Xu Y, Ku BS, Yao HY, et al. The effects of curcumin on depressivelike behaviors in mice. Eur J Pharmacol 2005; 518(1): 40-6. [http://dx.doi.org/10.1016/j.ejphar.2005.06.002] [PMID: 15987635]

[62] Kim DS, Park SY, Kim JK. Curcuminoids from Curcuma longa L. (Zingiberaceae) that protect PC12 rat pheochromocytoma and normal human umbilical vein endothelial cells from betaA(1-42) insult. Neurosci Lett 2001; 303(1): 57-61

[http://dx.doi.org/10.1016/S0304-3940(01)01677-9] [PMID: 11297823]

[63] Hansson GK, Robertson AK, Söderberg-Nauclér C. Inflammation and atherosclerosis. Annu Rev Pathol 2006; 1: 297-329.

[http://dx.doi.org/10.1146/annurev.pathol.1.110304.100100] [PMID: 18039117]

[64] Ansell BJ. Targeting the anti-inflammatory effects of high-density lipoprotein. Am J Cardiol 02007; 100(11 A): n3-9. [http://dx.doi.org/10.1016/j.amjcard.2007.08.006]

[65] McCormick ML, Gavrila D, Weintraub NL. Role of oxidative stress in the pathogenesis of abdominal aortic aneurysms. Arterioscler Thromb Vasc Biol 2007; 27(3): 461-9.

[http://dx.doi.org/10.1161/01.ATV.0000257552.94483.14] [PMID: 17218601]

[66] Srivastava R, Dikshit M, Srimal RC, Dhawan BN. Anti-thrombotic effect of curcumin. Thromb Res 1985; 40(3): 413-7.

[http://dx.doi.org/10.1016/0049-3848(85)90276-2] [PMID: 4082116]

[67] Pillarisetti S, Saxena U. Role of oxidative stress and inflammation in the origin of Type 2 diabetes--a paradigm shift. Expert Opin Ther Targets 2004; 8(5): 401-8.

[http://dx.doi.org/10.1517/14728222.8.5.401] [PMID: 15469391]

[68] Nishiyama $\mathrm{T}$, Mae $\mathrm{T}$, Kishida $\mathrm{H}$, et al. Curcuminoids and sesquiterpenoids in turmeric (Curcuma longa L.) suppress an increase in blood glucose level in type 2 diabetic KK-Ay mice. J Agric Food
Chem 2005; 53(4): 959-63.

[http://dx.doi.org/10.1021/jf0483873] [PMID: 15713005]

[69] Kobayashi T, Hashimoto S, Horie T. Curcumin inhibition of Dermatophagoides farinea-induced interleukin-5 (IL-5) and granulocyte macrophage-colony stimulating factor (GM-CSF) production by lymphocytes from bronchial asthmatics. Biochem Pharmacol 1997; 54(7): 819-24.

[http://dx.doi.org/10.1016/S0006-2952(97)00220-7] [PMID: 9353136]

[70] Shen SQ, Zhang Y, Xiang J-J, Xiong C-L. Protective effect of curcumin against liver warm ischemia/reperfusion injury in rat model is associated with regulation of heat shock protein and antioxidant enzymes. World J Gastroenterol 2007; 13(13): 1953-61. [http://dx.doi.org/10.3748/wjg.v13.i13.1953] [PMID: 17461496]

[71] Tourkina E, Gooz P, Oates JC, Ludwicka-Bradley A, Silver RM, Hoffman S. Curcumin-induced apoptosis in scleroderma lung fibroblasts: Role of protein kinase cepsilon. Am J Respir Cell Mol Biol 2004; 31(1): 28-35.

[http://dx.doi.org/10.1165/rcmb.2003-0354OC] [PMID: 14742295]

[72] Tønnesen HH, de Vries H, Karlsen J, Beijersbergen van Henegouwen G. Studies on curcumin and curcuminoids. IX: Investigation of the photobiological activity of curcumin using bacterial indicator systems. J Pharm Sci 1987; 76(5): 371-3.

[http://dx.doi.org/10.1002/jps.2600760506] [PMID: 3309256]

[73] Barthelemy S, Vergnes L, Moynier M, Guyot D, Labidalle S, Bahraoui E. Curcumin and curcumin derivatives inhibit Tat-mediated transactivation of type 1 human immunodeficiency virus long terminal repeat. Res Virol 1998; 149(1): 43-52.

[http://dx.doi.org/10.1016/S0923-2516(97)86899-9] [PMID: 9561563]

[74] Joe B, Rao UJ, Lokesh BR. Presence of an acidic glycoprotein in the serum of arthritic rats: Modulation by capsaicin and curcumin. Mol Cell Biochem 1997; 169(1-2): 125-34.

[http://dx.doi.org/10.1023/A:1006877928703] [PMID: 9089639]

[75] Anand P, Sundaram C, Jhurani S, Kunnumakkara AB, Aggarwal BB. Curcumin and cancer: An "old-age" disease with an "age-old" solution. Cancer Lett 2008; 267(1): 133-64.

[http://dx.doi.org/10.1016/j.canlet.2008.03.025] [PMID: 18462866]

[76] Srimal RC, Dhawan BN. Pharmacology of diferuloyl methane (curcumin), a non-steroidal anti-inflammatory agent. J Pharm Pharmacol 1973; 25(6): 447-52.

[http://dx.doi.org/10.1111/j.2042-7158.1973.tb09131.x] [PMID: 4146582]

[77] Ukil A, Maity S, Karmakar S, Datta N, Vedasiromoni JR, Das PK. Curcumin, the major component of food flavour turmeric, reduces mucosal injury in trinitrobenzene sulphonic acid-induced colitis. Br J Pharmacol 2003; 139(2): 209-18.

[http://dx.doi.org/10.1038/sj.bjp.0705241] [PMID: 12770926]

[78] Funk JL, Oyarzo JN, Frye JB, et al. Turmeric extracts containing curcuminoids prevent experimental rheumatoid arthritis. J Nat Prod 2006; 69(3): 351-5.

[http://dx.doi.org/10.1021/np050327j] [PMID: 16562833]

[79] Gukovsky I, Reyes CN, Vaquero EC, Gukovskaya AS, Pandol SJ. Curcumin ameliorates ethanol and nonethanol experimental pancreatitis. Am J Physiol Gastrointest Liver Physiol 2003; 284(1): G85-95.

[http://dx.doi.org/10.1152/ajpgi.00138.2002] [PMID: 12488237]

[80] López-Lázaro M. Anticancer and carcinogenic properties of curcumin: Considerations for its clinical development as a cancer chemopreventive and chemotherapeutic agent. Mol Nutr Food Res 2008; 52(Suppl. 1): S103-27.

[http://dx.doi.org/10.1002/mnfr.200700238] [PMID: 18496811]

[81] National Toxicology Program. NTP Toxicology and Carcinogenesis Studies of Turmeric Oleoresin (CAS No. 8024-37-1) (Major Component 79\%-85\% Curcumin, CAS No. 458-37-7) in F344/N Rats and B6C3F1 Mice (Feed Studies). Natl Toxicol Program Tech Rep Ser. 1993.427:1-275..

[82] Bharti AC, Donato N, Singh S, Aggarwal BB. Curcumin (diferuloylmethane) down-regulates the constitutive activation of nuclear factor-kappa B and IkappaBalpha kinase in human multiple myeloma cells, leading to suppression of proliferation and induction of apoptosis. Blood 2003; 101(3): 1053-62.

[http://dx.doi.org/10.1182/blood-2002-05-1320] [PMID: 12393461]

[83] Aggarwal BB, Shishodia S, Takada Y, et al. Curcumin suppresses the paclitaxel-induced nuclear factor-kappaB pathway in breast cancer cells and inhibits lung metastasis of human breast cancer in nude mice. Clin Cancer Res 2005; 11(20): 7490-8.

[http://dx.doi.org/10.1158/1078-0432.CCR-05-1192] [PMID: 16243823] 
[84] Kamat AM, Sethi G, Aggarwal BB. Curcumin potentiates the apoptotic effects of chemotherapeutic agents and cytokines through down-regulation of nuclear factor-kappaB and nuclear factor-kappaBregulated gene products in IFN-alpha-sensitive and IFN-alpha-resistant human bladder cancer cells. Mol Cancer Ther 2007; 6(3): 1022-30. [http://dx.doi.org/10.1158/1535-7163.MCT-06-0545] [PMID: 17363495]

[85] Kunnumakkara AB, Guha S, Krishnan S, Diagaradjane P, Gelovani J, Aggarwal BB. Curcumin potentiates antitumor activity of gemcitabine in an orthotopic model of pancreatic cancer through suppression of proliferation, angiogenesis, and inhibition of nuclear factor-kappaBregulated gene products. Cancer Res 2007; 67(8): 3853-61. [http://dx.doi.org/10.1158/0008-5472.CAN-06-4257] [PMID: 17440100]

[86] Nadrowski P, Chudek J, Skrzypek M, et al. Associations between cardiovascular disease risk factors and IL-6 and hsCRP levels in the elderly. Exp Gerontol 2016; 85(85): 112-7.

[http://dx.doi.org/10.1016/j.exger.2016.10.001] [PMID: 27729238]

[87] Henry CJ, Huang Y, Wynne A, et al. Minocycline attenuates lipopolysaccharide (LPS)-induced neuroinflammation, sickness behavior, and anhedonia. J Neuroinflammation 2008; 5(5): 15. [http://dx.doi.org/10.1186/1742-2094-5-15] [PMID: 18477398]

[88] Zhang Y, Liu L, Peng Y-L, et al. Involvement of inflammasome activation in lipopolysaccharide-induced mice depressive-like behaviors. CNS Neurosci Ther 2014; 20(2): 119-24 [http://dx.doi.org/10.1111/cns.12170] [PMID: 24279434]

[89] Grivennikov S, Karin E, Terzic J, et al. IL-6 and Stat3 are required for survival of intestinal epithelial cells and development of colitisassociated cancer. Cancer Cell 2009; 15(2): 103-13 [http://dx.doi.org/10.1016/j.ccr.2009.01.001] [PMID: 19185845]

[90] Lin Y, Yang X, Liu W, et al. Chemerin has a protective role in hepatocellular carcinoma by inhibiting the expression of IL-6 and GMCSF and MDSC accumulation. Oncogene 2017; 36(25): 3599-608. [http://dx.doi.org/10.1038/onc.2016.516] [PMID: 28166197]

[91] Subhash Bagad Ashish, Allan Joseph Joshua, Natarajan Bhaskaran, Amit Agrawal. Comparative Evaluation of Anti-Inflammatory Activity of Curcuminoids, Turmerones, and Aqueous Extract of Curcuma long 2013; (7): 805756.

[92] Cheng AL, Hsu CH, Lin JK, Hsu MM, Ho YF, et al. Phase I clinical trial of curcumin, a chemopreventive agent, in patients with high-risk or pre-malignant lesions. 2001; 21(4B): 2895-900.

[93] Satoskar RR, Shah SJ, Shenoy SG. Evaluation of anti-inflammatory property of curcumin (diferuloyl methane) in patients with postoperative inflammation. Int J Clin Pharmacol Ther Toxicol 1986; 24(12): 651-4.

[PMID: 3546166]

[94] Bundy R, Walker AF, Middleton RW, Booth J. Turmeric extract may improve irritable bowel syndrome symptomology in otherwise healthy adults: A pilot study. J Altern Complement Med 2004; 10(6): 1015-8. [http://dx.doi.org/10.1089/acm.2004.10.1015] [PMID: 15673996]

[95] Chandran B, Goel A. A randomized, pilot study to assess the efficacy and safety of curcumin in patients with active rheumatoid arthritis. Phytother Res 2012; 26(11): 1719-25.

[http://dx.doi.org/10.1002/ptr.4639] [PMID: 22407780]

[96] Paolino D, Vero A, Cosco D, et al. Improvement of Oral Bioavailability of Curcumin upon Microencapsulation with Methacrylic Copolymers. Front Pharmacol 2016; 7(7): 485. [http://dx.doi.org/10.3389/fphar.2016.00485] [PMID: 28066239]

\section{(c) 2019 Wal et al.}

This is an open access article distributed under the terms of the Creative Commons Attribution 4.0 International Public License (CC-BY 4.0), a copy of which is available at: (https://creativecommons.org/licenses/by/4.0/legalcode). This license permits unrestricted use, distribution, and reproduction in any medium, provided the original author and source are credited. 